\title{
OS ADAPTADORES DO QUIXOTE MAIS PUBLICADOS NO BRASIL ${ }^{1}$
}

\author{
Silvia Cobelo
}

Si ella [la historia] fuere buena, fiel y verdadera, tendrá siglos de vida; pero si fuere mala, de su parto a la sepultura no será muy largo el camino.

CERVANTES

Neste ano festejamos o quarto centenário $O$ engenhoso cavaleiro dom Quixote de la Mancha, segunda parte do grande livro de Cervantes, escrito em 1605 e 1615. Além de eventos acadêmicos e para o público em geral, assistimos a documentários, entrevistas e ao frenesi na indústria editorial. A obra espanhola nunca havia sido tão publicada no Brasil como nesse período; somente em 2005 foram lançados 15 novos livros, além de 12 republicações ${ }^{2}$, e a partir desse ano aparecem gêneros inéditos na história das adaptações ${ }^{3}$ da obra, como quadrinhos, graphic novel e versos de cordel, além de títulos escritos no exterior e traduzidos para o português.

O Quixote e outros títulos clássicos da Literatura infanto-juvenil (daqui em diante, LIJ), nos quais se incluem as adaptações de cânones da literatura adulta, foram apropriados pelos mais jovens e rapidamente absorvidos pelo sistema educacional. Essa literatura surge durante a segunda metade do século XVII e o início do XVIII principalmente no norte da Europa ocidental e acompanhou a evolução da sociedade moderna, com o estabelecimento da classe média, a explosão demográfica urbana do século XIX e o crescente número de alfabetizados pela introdução da escolarização obrigatória (O’Sullivan, 2009, p. 54; Soriano, 2001, p. 26).

\footnotetext{
${ }^{1}$ Este artigo foi feito com dados apresentados na tese de doutoramento defendida dia 9 de abril, 2015 na FFLCH-USP. Parte do material foi apresentado em um artigo publicado no livro Translators Have Their Say?: Translation and Power of Agency, Abdel Wahab Khalifa (ed.), "Adaptations of Don Quijote: Discussing Adults' Retranslations of the Classics for Children".

${ }_{2}$ Republicar, palavra dicionarizada no Aulete, significa publicar novamente. O problema é sempre distinguir reedições de reimpressões, dois termos que, apesar de padronizados pela ABNT e ISBN, ainda são usados de maneira algo aleatória. Muitas vezes não é possível saber se o exemplar foi reeditado ou apenas reimpresso, portanto preferimos usar republicação, acepção que inclui as duas ações, editar e/ou imprimir novamente.

${ }^{3}$ Neste artigo definimos adaptação de acordo com Julie Sanders (2006: 18-19), um texto modificado, mas que pode ser reconhecido como derivado de outro anterior. Nas apropriações o novo texto afasta-se muito mais da sua matriz, e apesar de conservar características da fonte, a nova obra é muito mais do reescritor que do autor do texto de partida (Sanders, 2013: 26-41). As adaptações e apropriações se distinguem das traduções integrais por não transladarem completamente todo o texto da obra, reescrevendo partes, sintetizando/resumindo todos ou alguns episódios da fonte.
} 
Em muitas ex-colônias, como no caso do Brasil, os livros destinados ao público jovem surgiram no início como importações vindas do país colonizador. Não é possível traçar uma história do Quixote na LIJ brasileira sem incluir as pessoas e instituições que promoveram sua recepção, descobrir quem eram e quais eram suas inter-relações e autoridade na construção da fama literária da obra no país. Nesse ponto estamos de acordo com Pym (1998, p. 158-159) quando traz o conceito de multiplicidade causal, vários agentes e circunstâncias históricas agindo juntas. Assim como em "Tradutores do Quixote”, publicado nesta mesma Tradução em Revista em 2010, este artigo tem como objetivo colaborar com os estudos de recepção do romance de Cervantes, focando aqui as biografias de cada um dos responsáveis pelos Quixotes mais publicados no país, disponibilizando trechos de entrevistas inéditas, assim como algumas informações sobre as casas editoriais.

\section{Os dez adaptadores mais publicados}

Após a confecção de um inclusivo catálogo com as 74 edições e suas republicações ${ }^{4}$, constatamos versões com apenas uma ou, no máximo, duas reimpressões, mas percebemos constância de certos títulos ao longo do tempo, em especial as obras de Monteiro Lobato, Orígenes Lessa e José Angeli escritas em 1936, 1970 e 1985, respectivamente, e republicadas até hoje quase sem interrupções. Apesar de repaginadas com atraentes projetos gráficos, novas ilustrações e em versões eletrônicas, apresentam os mesmos textos, apenas com atualizações ortográficas. Notamos algo semelhante com as obras de alguns adaptadores deste século, como Ferreira Gullar e Walcyr Carrasco (2002), e aquelas lançadas em 2005, assinadas por Leonardo Chianca, Rosana Rios e Ana Maria Machado, ou a adaptação preparada em 2008 por Fábio Bortolazzo Pinto, sinalizando um desequilíbrio de recepção dentro do universo das 74 versões da obra publicadas no Brasil nestes 127 anos: algumas poucas versões são continuamente republicadas enquanto a grande maioria não chega a ter mais que uma ou duas reedições, muitas vezes nem são reimpressas.

\footnotetext{
${ }^{4}$ Anthony Pym (1998:38-42) chama de catálogos as listas de traduções dentro de um campo específico e aconselha que sejam feitos de forma mais completa possível, sendo capazes de proporcionar busca de informações específicas. A presente pesquisa sobre as adaptações do Quixote originou-se com a confecção de uma listagem prévia das adaptações que surgiram durante a elaboração da dissertação de mestrado sobre a história das traduções integrais da obra publicadas no Brasil de 1943 a 2009 (Cobelo, 2009). Esse listado, foi completado e transformado em um inédito catálogo com as 74 edições distintas de adaptações e apropriações do Quixote (Anexo eletrônico da tese, em breve no Banco de Teses da USP) com 325 capas das mesmas (entre reimpressões e reedições), cobrindo 127 anos de recepção (1886-2013).
} 
Como neste caso se desejava identificar a recepção brasileira do livro cervantino a partir de uma abordagem historiográfica, para elaborar o catálogo com dados bibliográficos de cada exemplar seguiu-se o protocolo sugerido por Anthony Pym (1998, p. 38-42), crítico que aponta não ser possível reconstruir a história da tradução de uma obra, ou testar hipóteses relativas à mesma, apenas analisando algumas obras isoladas, e também alguns dos critérios utilizados na tese de Marcia Martins (1999) e no portal Escolha seu Shakespeare, organizado pela mesma pesquisadora ${ }^{5}$. Escolhemos as dez adaptações brasileiras mais publicadas no Brasil para integrar nosso corpus de pesquisa ${ }^{6}$, todas em prosa. $\mathrm{O}$ fato de serem encontradas muitas traduções e reedições de antigas traduções poderia ser considerado como um bom índice da demanda do público leitor. Neste tipo de pesquisa, muitas vezes não são conseguidos dados como tiragens e vendas reais, portanto, a frequência das reedições geraria um panorama dessa demanda (Pym, 1998, p. 79). A pesquisa resultou em uma discussão instigante envolvendo autoria, agentes e manipulação de fama literária.

\section{Metodologia para coleta de dados sobre os adaptadores}

Por ser este um estudo da recepção do Quixote no Brasil através de suas reescrituras, neste caso as adaptações, daremos mais importância aos tradutores/adaptadores, analisando comparativamente as obras dos dez mais publicados e fundamentando a pesquisa com os estudos de críticos como Jenny Williams e Andrew Chesterman (2002, p. 16-17) e de Antony Pym (1998, p. 160-176), que creditam a esses indivíduos um papel fundamental dentro da história da tradução. A biografia abrange informações sobre cada um deles, se eram tradutores e/ou adaptadores profissionais, desde quando, quantas línguas sabiam, como as aprenderam, se conheciam o exterior e se eram polivalentes e tinham e/ou haviam tido outras atividades além de traduzir ${ }^{7}$.

\footnotetext{
${ }^{5}$ Escolha seu Shakespeare Disponível em: http://www.dbd.puc-rio.br/shakespeare/default.php. Acesso em 16 maio 2015.

${ }^{6}$ Justamente para obter maior representatividade, optou-se por escolher precisamente essas obras, as quais deveriam também se encaixar nos seguintes parâmetros:

a) ser uma obra em prosa e em formato de livro, não folheto (mais de 49 páginas);

b) texto criado pelo autor em português (não ser uma tradução de uma reescritura estrangeira);

d) publicado (incluindo reimpressões, reedições) pelo menos oito vezes, ou cinco, dependendo de se a obra foi publicada no século XX ou século XXI.

Apenas como exemplo, ao confeccionar o catálogo coletamos, entre reedições e reimpressões, 66 distintas capas de Lobato, 28 de Lessa, 49 de Angeli e um número entre 5 a 9 para os adaptadores do século XXI.

${ }^{7}$ No artigo "Humanizing Translation History", Pym (2008, p. 18) discorre sobre as várias atividades dos tradutores, os quais, como vemos a seguir, geralmente fazem mais do que traduzir: eles ocupam muitas
} 
Buscou-se revelar a relação destes com o círculo de intelectuais e artistas que tenham colaborado com seu capital cultural, assim como editores e casas editoriais. Como parte desse perfil, reuniram-se informações sobre suas outras traduções e criações, e, como estamos dentro do tema literatura infantojuvenil, quando começaram a escrever para crianças e jovens. Procurou-se descobrir também questões relativas à adaptação/tradução da obra cervantina em si: suas motivações e seus métodos de trabalho, sua participação na escolha das ilustrações, paratextos e autoridade dentro de sua reescritura, e a questão dos copyrights.

Para elaborar as biografias, além da pesquisa bibliográfica e buscas na internet ${ }^{8}$, utilizamos o material recolhido durante nossas entrevistas com os tradutores/adaptadores e alguns editores, seguindo o protocolo de Peter Flynn (2003). O roteiro de perguntas foi escrito após extensa investigação sobre a vida e as atividades da pessoa a ser entrevistada. Procurou-se estabelecer uma conexão ao dizer que esta pesquisadora é também uma tradutora, recriando suas trajetórias através de entrevistas diretas, informando-os do projeto de pesquisa em questão, fazendo o possível para elaborar questões semiestruturadas e abertas, apenas para saber, segundo a versão de cada entrevistado, como aconteceu cada adaptação do Quixote. As entrevistas foram enviadas antes por e-mail, e completadas por telefone ou visita pessoal. O entrevistador, segundo Flynn, deve iniciar a conversa com perguntas casuais, tentando obter a confiança do interlocutor, para depois entrar no tema da adaptação realizada. Esse contato direto é complexo, muitas vezes os entrevistados não se lembram (ou não querem se lembrar) de detalhes de uma produção feita uma década atrás; ou desviam das questões, mas também discorrem sobre assuntos que não levantados pela entrevista. As perguntas, às vezes algo extensas, fazem parte do método: o entrevistado percebe o trabalho de pesquisa realizado por trás daquelas questões e se sente valorizado, algo que pode ser confirmado pela reação positiva dos entrevistados.

\section{Carlos Jansen, das armas às letras}

O primeiro Quixote publicado no Brasil foi uma adaptação. Editado em 1886, D. Quixote de la Mancha apresenta uma curiosa genética alemã tripla. Publicada pela editora Laemmert \& Co, fundada por dois livreiros da Alemanha, e o texto segue uma

vezes posições mediadoras, como professores, jornalistas, críticos literários e outros que intermedeiam vários aspectos de comunicação intercultural [cross-cultural communication], assim chamada pelo crítico. ${ }^{8}$ Ver sobre protocolos para pesquisas na internet em Cobelo (2010, p. 3). 
adaptação de Franz Hoffmann (1844) ${ }^{9}$, reescrito para a juventude brasileira pelo teutobrasileiro Carlos Jansen (1829-1889). Nascido em Colônia, Jansen foi um dos 1.800 mercenários alemães contratados pelo imperador brasileiro para lutar na Guerra da Cisplatina (1825-1828). Ao final do conflito, como muitos Brummers, Jansen preferiu ficar no Rio Grande do Sul $^{10}$. Naturalizado brasileiro, depois de publicar seu primeiro romance, lançou em 1863 uma gramática, primeiro livro de uma extensa lista de obras para uso escolar que ele publicaria mais tarde no Rio de Janeiro ${ }^{11}$. Nessa época ainda exercia a função de inspetor de colonização, atuando como agente intérprete de imigrantes que chegavam ao Rio Grande do Sul (Laytano, 1974, p. 39 e 63). Depois de um curto período de tempo na Argentina, local em que nasce seu oitavo filho, mudou-se para Rio de Janeiro em 1878, onde permaneceu até sua morte como professor da cátedra de Língua e Literatura Alemã no prestigiado Colégio Pedro II.

Jansen é considerado um pioneiro da LIJ brasileira, não só por ter assinado as primeiras traduções de clássicos infantis, mas também pela consciência da necessidade de ter esses livros disponíveis em português do Brasil ${ }^{12}$. O século estava terminando e o jovem país mudava rapidamente. Após a abolição da escravatura (1888) e proclamação da República (1889), iniciou-se um processo de modernização caracterizado por uma crescente população urbana composta de escravos libertos e imigrantes, propiciando o surgimento de um novo público leitor (Zilberman e Lajolo, 1986, p. 15). A segunda edição sai em 1901 com o selo Laemmert \& Cia, nome que os herdeiros dos irmãos germânicos deram à empresa em 1891. Nos anos 1940 o texto foi modificado, resumido para essa reedição da Editora Minerva $(\mathrm{RJ})$ e republicado pelo menos seis vezes, antes

\footnotetext{
${ }^{9} \mathrm{Na}$ primeira página há uma inscrição: "Redigido a Mocidade Brasileira, segundo o plano de F.Hoffmann, por Carlos Jansen do Colégio D. Pedro II". Como as adaptações foram analisadas dentro da perspectiva dos Estudos Descritivos da Tradução [Descriptive Translation Studies], consideramos muito relevante como o texto se apresenta ao público na cultura de chegada (Toury, 1995, p. 86). Em breve publicaremos uma pesquisa com a colaboração de um colega da área, comparando as duas obras, mas desde já podemos inferir que o texto de Hoffmann foi adaptado, e não traduzido integralmente.

${ }^{10}$ Brummer significa resmungão. Apenas trezentos soldados voltaram para a Alemanha, os outros aceitaram terras, transformando-se em comerciantes, agrimensores, médicos e professores, e até mesmo políticos.

${ }^{11}$ Adaptou diversos livros didáticos escritos originalmente em inglês, francês e alemão, lançados entre 1880 e 1885 pela Laemmert.

${ }^{12}$ Outras adaptações literárias lançadas pela Laemmert: Contos seletos das Mil e uma noites (1882), Robinson Crusoé e Contos seletos (contos europeus) em 1885, Viagens de Gulliver às terras desconhecidas (1888), Aventuras pasmosas do celebérrimo Barão de Münchausen ou a fiel e verídica narrativa das memórias extraordinárias e aventuras admiráveis daquele narrador imortal (1891), Contos para filhos e netos [1889?] (Laytano, 1974, p. 40-41 e Hohlfeldt, 2003, p. 70-71). Leonardo Arroyo (1968, p. 175) acredita que ele tenha traduzido, mas sem receber o devido crédito e muitos contos de autores alemães para os leitores brasileiros.
} 
da década de sessenta. Observamos uma tradução intralingual da obra escrita em 1886, na qual se mutila o texto, subtraindo o elegante estilo e qualidades como os saborosos diálogos entre escudeiro e cavaleiro, quase todos transformados em discurso indireto. Esse resumo sem maiores atrativos é anunciado como "edição inteiramente refundida por Terra de Senna" (Jansen/Senna, 1956:3), pseudônimo do escritor, jornalista, dramaturgo, poeta e humorista Lauro Nunes (1896-1972), e as últimas edições não mencionam Carlos Jansen. Em 1982, a mesma versão desfigurada foi publicada pela última vez pela desconhecida MCA, com todos os créditos de adaptação omitidos.

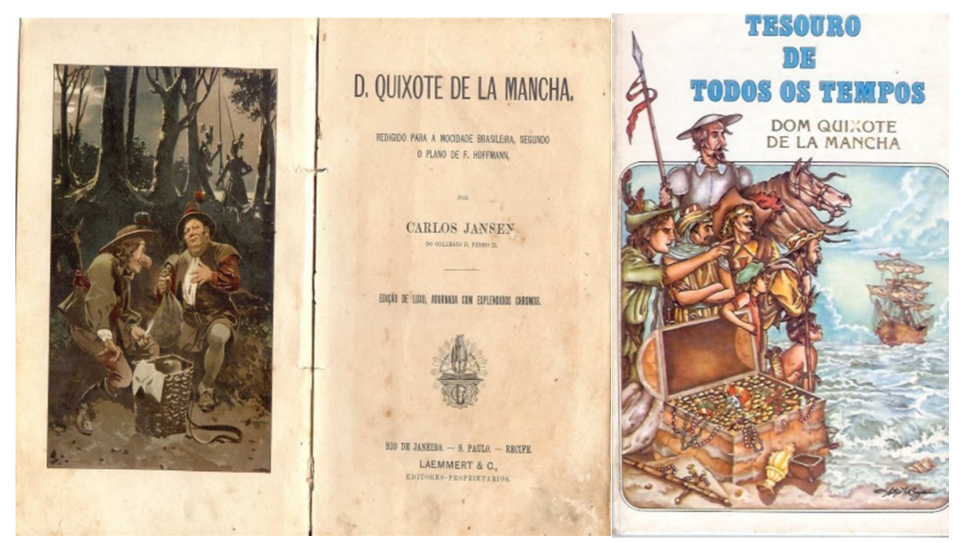

CLaemmert \& C., 1901 @MCA Editorial e Gráfica, 1982

\section{Monteiro Lobato e seu clássico: "Dom Quixote das Crianças"}

Os jovens leitores tiveram que esperar 50 anos para ler uma nova versão do Quixote. O Brasil e o mundo haviam mudado muito; as crianças queriam algo novo, não uma antiquada versão escrita no século $\mathrm{XIX}^{13}$. José Bento Monteiro Lobato (1882-

\footnotetext{
${ }^{13}$ Monteiro Lobato sempre procurou trazer o texto mais próximo do leitor, declarando querer "abrasileirar a linguagem" (Lobato, 1957, p. 274), célebre frase originalmente encontrada em uma carta escrita em 1925 para seu amigo Rangel quando se refere ao seu projeto para adaptar a obra de Cervantes: "O $D$. Quixote é para ver se vale a pena traduzir. [...] Estou a examinar os contos de Grimm dados pelo Garnier. Pobres crianças brasileiras! Que traduções galegais [sic]! Temos que refazer tudo isso - abrasileirar a linguagem" (Lobato, 1957, p. 274). Antes disso, em junho de 1921, Lobato, falando como editor da Companhia Editora Nacional, diz ao amigo: "Pretendemos lançar uma serie de livros para crianças, como Gulliver, Robinson, etc., os clássicos, e vamos nos guiar por umas edições do velho Laemmert, organizadas por Jansen Müller. Quero a mesma coisa, porém com mais leveza e graça de língua. Creio até que se pode reescrever aquilo em língua desliteraturizada - porque a desgraça da maior parte dos livros é sempre o excesso de 'literatura'. [...] É só ir eliminando todas as complicações estilísticas do 'burro'. Se não tens por aí essas edições do Laemmert, mandarei” (Lobato, 1957, p. 233, itálicos e aspas do autor). As contínuas menções aos livros adaptados por Jansen e ao Dom Quixote da juventude, tradução portuguesa de uma adaptação franco-espanhola editada pela Garnier, contribuíram para a errônea conclusão de Laurence Hallewell (2005), que ao analisar a participação de Lobato nas primeiras traduções e adaptações para o público infanto-juvenil chega a afirmar que a editora de Lobato lançava versões dessas obras: "Viagens de Gulliver, de Robinson Crusoé, e de D. Quixote, com base nas traduções
} 
1948), escritor, tradutor/adaptador, editor, e figura central no desenvolvimento da indústria editorial brasileira, percebeu essa necessidade e mudou a LIJ brasileira para sempre, criando uma herança lobatiana. Após uma infância tranquila de um menino do interior (Taubaté-SP) e coalhada de leituras — além de tentar caçar sacis, desbravava a biblioteca de seu avô visconde, de onde tinham de tirá-lo à força (Cavalheiro, 1962, p. 10), época em que deve ter lido Robinson e outros da mesma coleção ${ }^{14}$. Ao se formar em direito no Largo São Francisco, aceitou em 1904 um cargo de promotor em Areias (SP), e matando seu tempo ocioso publicando artigos que traduzia do Weekly Times (Lobato, 1964, p. 226 e 250). Em 1918 vendeu a fazenda que herdara e compra a Revista do Brasil, uma das primeiras pontes culturais latino-americanas, e se transformou em um ousado editor, montou um catálogo com nomes novos, como Lima Barreto, Oswald de Andrade, Menotti del Pichia, e entrou no mercado sempre lucrativo dos livros escolares, publicando o famoso Narizinho arrebitado. Nomeado adido comercial, viveu em Nova York (1927-1931) com sua mulher e quatro filhos, período em que continuou escrevendo e adaptando para crianças, mas perde quase todo o seu dinheiro em 1929 com o crash da bolsa. Ao voltar, divide seu tempo entre sua empresa de petróleo e sua produção de LIJ. Sempre em discussões com o governo Vargas, acabou sendo preso em 1941 após enviar cartas ao ditador e ficou seriamente endividado pelo insucesso da empresa petrolífera. O escritor manteve esse idealismo até sua morte: mesmo nos últimos meses de vida, continuava a agitar e panfletar, mimeografando entrevistas suas censuradas pela imprensa (Lobato, 1959, p. 313 e 319).

Lobato preparou a chegada do cavaleiro, mencionado a personagem em outros $\operatorname{livros}^{15}$, até finalmente, em 1936, lançar Dom Quixote das Crianças, pela Companhia Editora Nacional (1925-1970), reeditando-o em 1940, inserindo, assim, Dom Quixote das Crianças dentro da coleção Sítio do Picapau Amarelo. A adaptação foi publicada

portuguesas publicadas pela Garnier e pela Laemmert, mas com a linguagem cuidadosamente modernizada e abrasileirada" (Hallewell, 2005, p. 336).

14 "-No meu tempo de menino consegui reunir tudo quanto havia no mercado: três livros de Laemmert adaptados por um Jansen Müller, e dois álbuns de cenas coloridas - O Menino Verde e João Felpudo" (Lobato, 1964, p. 120).

${ }^{15}$ Dom Quixote é mencionado por Pedrinho em História do Mundo para Crianças (1933) e História das Invenções (1935). Almeida Prado (2007, p. 93) discute se foram ações de marketing, ou equívocos, como sustenta Acioli (2005, p. 185). As personagens do Sítio citam o cavaleiro logo no ano de lançamento, em Memórias de Emília (1936), repetindo a dose na Chave do Tamanho (1942) e Doze Trabalhos de Hércules (1944), mesmo ano da terceira edição do Quixote, primeira editada pela Brasilense. No livro $O$ Pica Pau Amarelo (1939), lançado um ano antes da segunda edição da adaptação cervantina, Dom Quixote visita o sítio e vive novas aventuras, em um caso típico de apropriação. 
pela Brasiliense continuamente entre $1944-2005^{16}$, e atualmente é publicada pela Editora Globo, com versões eletrônicas e em quadrinhos (2007).

Dom Quixote das Crianças somente foi traduzido duas vezes, e na Argentina. A primeira surge em 1937 assinada por Benjamín Bertoly de Garay (188?-1943), intelectual responsável por estabelecer uma das primeiras pontes culturais entre Argentina e Brasil (Cobelo, 2012). Mas apenas em 1945 a obra de Lobato seria conhecida em toda América hispana, através da coleção Picapau Amarelo, com 24 livros, entre eles, Dom Quixote das Crianças, vertido pelo ainda misterioso tradutor ou tradutora, M. de Sosa. A editorial Losada publicou e exportou a coleção até 1963, que hoje voltou a ser reeditada com financiamento da Embaixada do Brasil, com as mesmas traduções de 1944/1945, mas ilustrações de um artista brasileiro, Paulo Borges. O primeiro volume, Las Travesuras de Naricita (2010), apresenta uma introdução feita pela presidente Cristina Kirchner. La Quinta del Benteveo Amarillo foi muito bem promovida e Lobato renasceu nos meios de comunicação; podemos até encontrar blogs com pessoas de toda a América Latina ${ }^{17}$. A obra de Lobato foi adaptada várias vezes para o rádio e também para TV, sempre com o título Sítio do Picapau Amarelo. As mais estudadas são as duas feitas pela TV Globo, que, assim como a nova versão animada, foram exportadas para o mercado internacional ${ }^{18}$. Em resumo, isso significa que através das adaptações televisivas, legendadas ou dubladas, em forma de seriado ou animação, a mais famosa versão brasileira do Quixote rompeu fronteiras: linguísticas, culturais, temporais, e de meios de comunicação. A dupla manchega continua a divertir crianças pelo mundo inteiro, perpetuando a fama cervantina, claro que sob a ótica lobatiana, que influenciou várias gerações de adaptadores.

\footnotetext{
${ }^{16}$ Segundo Hallewell (2005, p. 661), a Brasilense estagnou no final da década de 1960 e sobreviveu graças às republicações das obras de Lobato.

${ }_{17}$ Alguns exemplos: El arte encuestión; http://elarteencuestion.blogspot.com.br/2010/04/el-companeromonteiro-lobato.html; Proyecto Cultural Sur: http://proyectoculturalsur.net/category/libros/page/2/; Siempre Libre: http://siemprelibrefm.blogspot.com.br/2010_04_01_archive.html. Archivos del Sur: http://archivosdelsur-lecturas.blogspot.com.br/2010/04/las-travesuras-de-naricita-monteiro.html. Revista Digital de Cultura MACEDONIO BELARTE: http://revistadigitalmacedonio3.blogspot.com.br/2011_02_01_archive.html. La página de Claudio: http://lapginadeclaudio.blogspot.com.br/2011_04_23_archive.html. Comisión "Nicolás Casullo" de medios audiovisuales co carta abierta: http://mediosencartaabierta.blogspot.com.br/2011_01_16_archive.html. Acessos em 16 maio 2015.

${ }^{18}$ As duas versões (1977-1986 e 2001-2007) foram transmitidas diariamente. Sabe-se que Dom Quixote das Crianças foi ao ar em 2002 e em 2005, com novos atores, para celebrar o centenário da obra. Retransmitida ainda hoje nos canais Viva e Futura, a série é exportada com o título Pirlimpimpim. Atualmente o Sítio se tornou um desenho animado, com abertura musical atualizada pelo próprio Gilberto Gil, com cerca de 60 produtos já licenciados. Sítio do Pica pau Amarelo. Disponível em: http://sitio.globo.com/\#downloads. Acesso em 29 jan. 2015.
} 


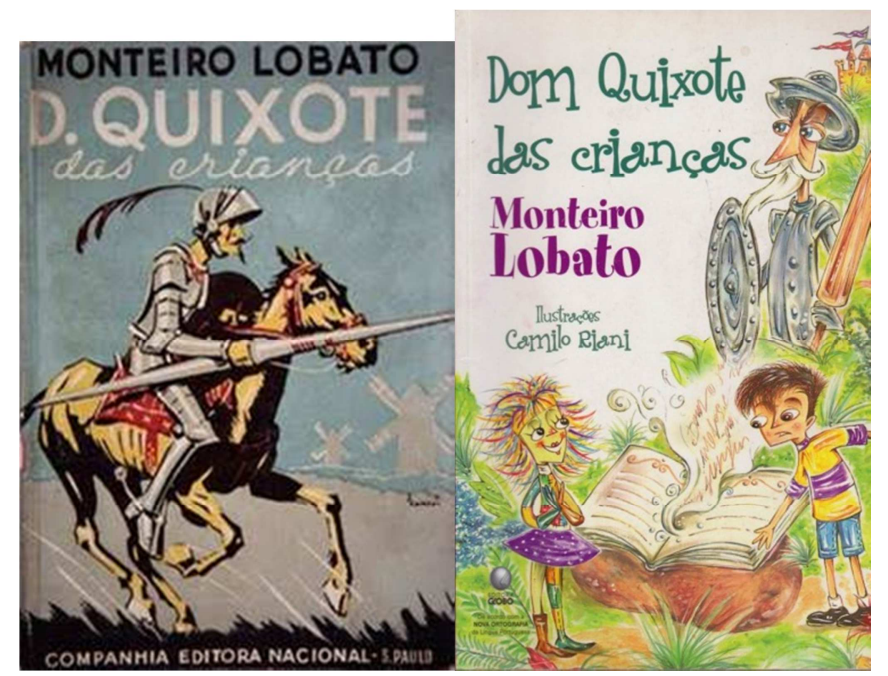

(C)Acervo Cia. da Memória, 1936@Editora Globo, 2013

\section{Orígenes Lessa, o escritor publicitário}

O próximo Dom Quixote tardou 35 anos para aparecer. A Ediouro (anteriormente Tecnoprint), uma das primeiras a publicar livros de bolso no Brasil, encomendou uma nova versão da obra a Orígenes Lessa (1903-1986). Nascido em Lençóis Paulista, era filho de missionário protestante e professor de grego, língua em que o menino Lessa escreveu sua primeira história aos oito anos. Apaixonado por livros, o Quixote era uma de suas leituras preferidas (Guedes, 2007, p. 2). Depois de dois anos de seminário, graduou-se em Educação Física no Rio de Janeiro, subsistindo como professor particular de inglês e publicando artigos e contos em periódicos. Após fazer traduções para uma exportadora de café ele foi contratado pela General Motors, onde permaneceu no departamento de propaganda até 1931, trabalhando depois disso sempre como publicitário, profissão que manteve durante quarenta anos, até se aposentar. Foi também diretor da Rádio Record de São Paulo, na qual leu histórias com Lobato no programa Hora Infantil, introduzindo o patrocínio de empresas em programas de rádios.

Preso após participar da Revolução Constitucionalista de 1932, viu nascer seu primeiro filho, Ivan Lessa ${ }^{19}$, em 1935. Trabalhou como publicitário e se mudou para Nova York durante a Segunda Guerra Mundial, como o editor de programas da NBC enviados ao Brasil. Ao voltar, alternou suas atividades de publicidade com seus escritos,

\footnotetext{
${ }^{19}$ Ivan Lessa, escritor e jornalista, colaborador de $O$ Pasquim, morreu em Londres em 2012, cidade na qual se exilou em 1978. Orígenes Lessa também foi casado com Edith Thomas, união que gerou um filho, Rubens Lessa, porém pouco foi encontrado sobre esse ramo familiar.
} 
sendo eleito membro da Academia Brasileira de Letras em 1981 (Guedes 2007, p. 1424).

Lessa deslanchou como escritor e adaptador de LIJ na década de 1970, época em que lançou outro best-seller, Memórias de um Cabo de Vassoura (1971), pela Ediouro, a mesma editora que o contratou para adaptar o Quixote, e na qual publicou a maior parte de seus livros infantojuvenis ${ }^{20}$, incluindo traduções, adaptações, além de sua própria ficção. Conseguiu-se pouco sobre a história específica dessa adaptação do Quixote, mas sabemos que a família Lessa está em disputa com a Ediouro por direitos autorais $^{21}$. Essa adaptação ainda é publicada pela Ediouro, e está disponível em formato e-book desde 2005.

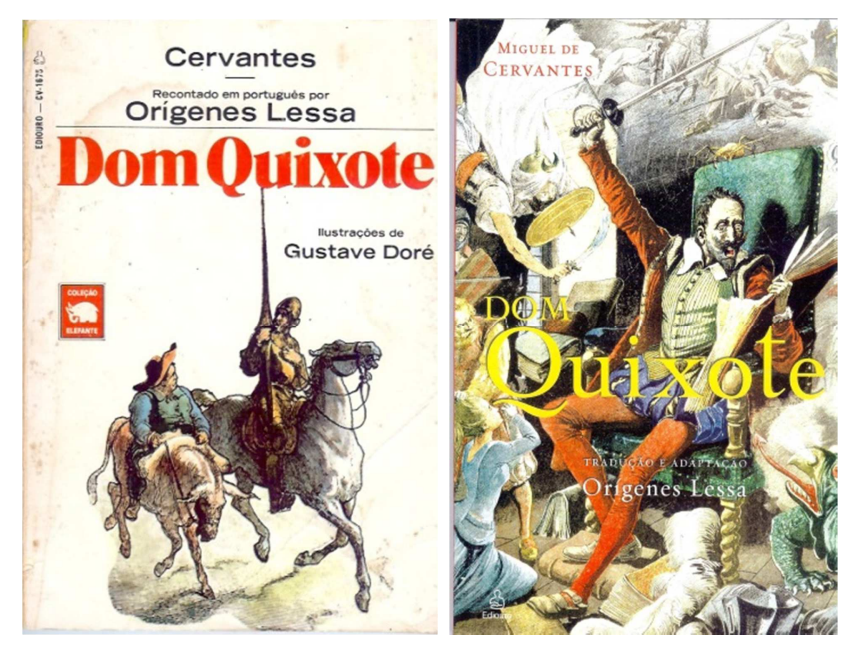

CEditora Tecnoprint [Ediouro], 1971 CLeonard de Selva/CORBIS, 2013

José Angeli, da guerrilha ao "Quixote”

O escritor José Angeli Sobrinho (1944-2012) aceitou a encomenda da Scipione de readaptar o Quixote, lançado em 1985 como primeiro número da Série Reencontro,

\footnotetext{
${ }^{20}$ Sua primeira obra infantil surge em 1934, O Sonho de Prequeté. Obteve fama com o Feijão e o Sonho (1939), sucesso de vendas, até hoje editado (Global Editora). Com 30 livros para adultos e 40 de LIJ, destacamos aqui, títulos baseados em Nathaniel Hawtorne, Ulisses na Ilha da Feiticeira; A Cabeça de Medusa e Outras Lendas Gregas; O Palácio de Circe e Outras Lendas Gregas; O Minotauro e outras lendas gregas; As Três Maçãs de Ouro, de 1967. Do mesmo ano ainda temos O Viajante do Tempo de R. L. Stine e depois Aventuras de Tom Sawyer e Memórias de Pickwick (1970), Aventuras do Barão de Munchausen (1975).

${ }^{21}$ Durante a ditadura militar (1964-1985), muitos intelectuais se refugiaram na literatura para sobreviver. Como esses autores (muitos também tradutores e adaptadores) recebiam apenas um único pagamento, como um trabalho de freelance, assinando um contrato de cessão definitiva de direitos, perdiam copyrights e consequentemente as porcentagens de vendas, com graves implicações, como o rebaixamento do status de adaptador e desvalorização das adaptações paradidáticas. Ver entrevista com a viúva de Orígenes Lessa em Monteiro (2006, p. 128).
} 
na qual os clássicos foram reescritos em versões mais curtas (máximo de 140 páginas) $)^{22}$.

Nascido em Aratiba-RS, Angeli passou a infância lendo livros trazidos da Argentina por seu pai, "clássicos da literatura universal em francês, italiano, espanhol e, claro, em português" (Angeli, 2007, p. 244). Morou no Paraná e, casado, muda-se para Alegrete em 1961. Mantem a família trabalhando como técnico em Contabilidade, e cursa a faculdade de Economia até o golpe militar de 1964.

As narrativas disponíveis sobre essa turbulenta época são ainda poucas, especialmente em relação a este pequeno e pouco conhecido grupo, o Movimento Comunista Revolucionário $(\mathrm{MCR})^{23}$. Foi preciso fazer o percurso de investigação descrito em nota [23] para descobrir como nosso poliglota e leitor voraz transformou-se aos 26 anos em guerrilheiro, entrou em um armazém de caça e pesca e roubou todos os armamentos, histórias que não estão nos paratextos de suas obras. O grupo foi dizimado depois de quatro ações algo rocambolescas. Angeli ficou preso entre 1971-1973, após ter sido brutalmente torturado ${ }^{24}$. Ao ser solto em 1973, mudou-se para Morretes (PR), onde trabalhou como agrimensor, mas foi em Curitiba que se tornou escritor (Miecoanski, 2012). Lançou duas obras em $1979^{25}$ e roteirizou HQ para adultos na editora Grafipar. Também como freelance, colaborou para jornais, revistas, programas de rádio e agências de publicidade. E pelo que escreveu seu amigo dessa época curitibana, Angeli continuou, mesmo depois de tudo, uma pessoa alegre, cercou-se da melhor safra de intelectuais de Curitiba, como Paulo Leminski e outros, com os quais se encontrava quase todos os dias. Morreu em Morretes em dezembro de 2012, infelizmente antes que pudéssemos entrevistá-lo.

\footnotetext{
${ }^{22}$ Milton (2001a, 2001b, 2002) fornece detalhes sobre tradução de literatura de massa e suas diferentes formas de padronização, como limites de numero de páginas, a fim de reduzir os custos de impressão e distribuição.

${ }^{23}$ Utilizamos a dissertação de Silva (2011) bem como o livro até pouco tempo inédito feito pelo Exército Brasileiro, Orvil, (1988), e a obra de Pinheiro Sales (2007), Confesso que peguei em armas, visando obter um panorama através de três visões, a acadêmica, e as narrativas dos dois lados do conflito. Os dados foram também comparados com a edição do Comitê Pró-Anistia geral dos presos políticos no Brasil, editada por Ventura em Portugal, 1976.

${ }^{24}$ Pinheiro Sales (2007, p. 89), ex-parceiro de armas, conta o final desta história. Angeli quase perdeu um olho após um murro recebido no pau de arara, mas era quem tentava travar conversas com os jovens interioranos que pensavam que seriam hipnotizados pelos terroristas comunistas que estavam nas celas que vigiavam ou, quem puxava canções italianas, fazia brincadeiras engraçadas e contava boas histórias criando vários finais diferentes para as narrativas, tornando o cárcere mais suportável.

${ }^{25}$ A cidade de Alfredo Souza (1979/2007), Prostituta por Opção - Amanhã não leremos jornais (1979) e O sino da madrugada (2011).
} 
Em 1985 escreveu Dom Quixote - O Cavaleiro da Triste Figura, cristalizando o epíteto muito apreciado no século XIX pelos românticos, livro ainda hoje republicado pela Scipione. Tal como aconteceu com Lessa, aceitou encomendas para verter outros clássicos para a mesma editora, na época uma empresa jovem, iniciando sua bemsucedida trajetória no ramo de paradidáticos. A adaptação de Angeli foi um dos primeiros grandes sucessos da coleção Reencontro Literatura, para qual adaptou outros livros dessa série Aventuras: Os Três Mosqueteiros (1994); Os Miseráveis (1995); O Conde de Monte Cristo (2001); Ilíada (2002) e Martín Fierro (1991) — único livro de LIJ seu não mais republicado atualmente - e Don Casmurro, uma abreviação de Machado de Assis, portanto, uma adaptação intralinguística ${ }^{26}$. O texto, como foi dito, continua o mesmo, e a primeira mudança na diagramação original só ocorreu em 2000, quando a capa foi alterada, mas apenas em 2007 foram atualizadas a diagramação e as ilustrações.

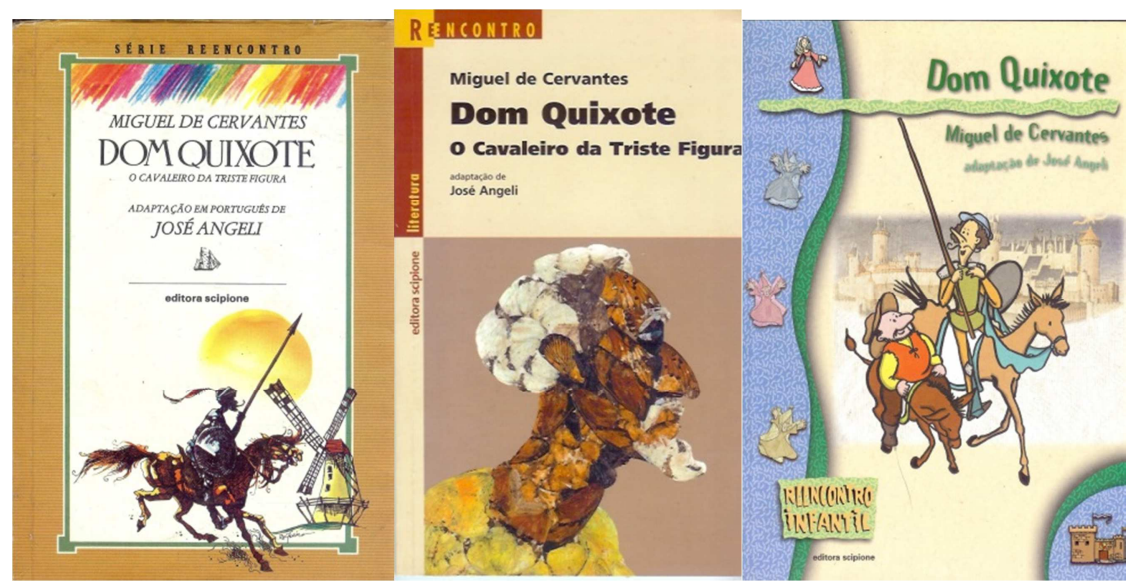

(C) Scipione, 1985 @Scipione, 2007 @Scipione, 2003

\section{Ferreira Gullar, o aclamado poeta}

Desde o início deste novo século, as celebrações do $400^{\circ}$ aniversário do Quixote foram marcadas por uma série de edições importantes. Um dos destaques foi a versão assinada pelo famoso poeta, tradutor e ensaísta José Ribamar Ferreira, nascido em São Luís, Maranhão, em 1930. Sem completar sua educação formal, mudou-se para o Rio de Janeiro em 1951 e trabalhou como revisor de revistas e jornais. Para Moura (2011, p. 62), sua trajetória em grandes redações o aproximou de vários intelectuais, "jornalistas e

\footnotetext{
${ }^{26}$ Em 2000, a mesma Scipione lançou em espanhol Don Quijote de la Mancha, uma adaptação didática assinada por Margarita Barberá Quiles, reeditado quase todos os anos, podendo assim atender o mercado escolar com diferentes versões.
} 
escritores de projeção que constituirão sua rede de contatos profissionais pelos anos seguintes", muitos conhecidos através de seu amigo, o influente crítico de arte Mário Pedrosa e de sua esposa, a atriz Thereza Aragão, de boa família carioca. Escreveu peças teatrais e em 1963 foi eleito presidente do CPC, Centro Popular de Cultura da União Nacional dos Estudantes. Filiou-se ao Partido Comunista Brasileiro um dia depois do golpe militar e continuou a manifestar seu repúdio as restrições e censuras impostas ao fundar o Grupo Opinião junto com sua esposa, Oduvaldo Viana Filho, Paulo Pontes e outros atores; mas em dezembro de 1969, ao ser decretado o AI-5, Gullar foi preso por alguns dias, acompanhado de Caetano Veloso, Gil e Paulo Francis.

Fugiu para Moscou e depois para Santiago, e, finalmente, para Buenos Aires, onde viveria até o seu retorno ao Rio, em 1977, quando foi preso e interrogado por 72 horas. No ano anterior havia sido lançada sua obra mais célebre, sem sua presença, o Poema Sujo. Escreveu roteiros para televisão ${ }^{27}$, recebeu vários prêmios literários, e em 2002 foi indicado para receber o Prêmio Nobel. No mesmo ano ele lançou seu Dom Quixote (2002), com ilustrações de Gustave Doré. A maioria das traduções que assinou foi feita por encomenda ${ }^{28}$, e exemplificando com sua tradução de Fábulas de la Fontaine (1997), alegou, como fez Lobato, o motivo histórico das retraduções: "Muitas das traduções que estão por aí nessa área são ilegíveis para crianças”. Assumindo sua visibilidade como autor, tradutor/adaptador, afirma ter modificado o texto: "tive então, de novo, liberdade para traduzir, às vezes alterando até a moral da história" (Gullar, 1998, p. 50).

Ferreira Gullar não detém os direitos autorais do livro, o qual, premiado pela Fundação Nacional do Livro Infantil e Juvenil (FNLIJ), está em sua quinta edição, com notas de rodapé (muito poucas), e sendo o mais caro dos nove livros do corpus que são vendidos no mercado. Assim como as suas versões de Mil e uma Noites e as Fábulas de la Fontaine, todos publicados pela Revan ${ }^{29}$, seu Quixote é anunciado como uma tradução, e neste caso, encontramos trechos inteiros praticamente traduzidos literalmente.

\footnotetext{
${ }^{27}$ Insensato Coração (1983), Aplauso (1979), para a qual adapta algumas peças de teatro de escritores como Lilian Helmann, Ionesco, Arthur Miller. Assina também episódios para Carga Pesada (1980) e Obrigada, Doutor (1981) e colabora com a novela Araponga (1990), e minisséries como As Noivas de Copacabana (1992), O fim do Mundo (1996) e Dona Flor e seus dois maridos (1997).

${ }_{28}$ Adaptou também: Antígona (1969); Ubu rei (1972), Cyrano de Bergerac (1985) e O país dos elefantes (1989).

${ }^{29}$ Empresa de porte médio, fundada 30 anos atrás no Rio de Janeiro por um antigo companheiro do adaptador, o editor Renato Guimarães.
} 


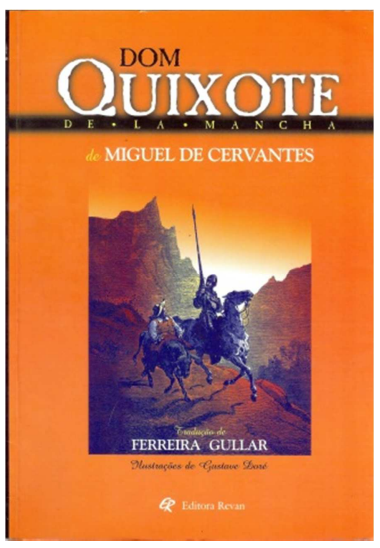

(ORevan, 2002

\section{Walcyr Carrasco, o escritor multimidiático}

Walcyr Carrasco (1951), paulista de Bernardino de Campos, inicia a série de adaptadores nascidos na segunda metade do século XX. Aos quinze anos foi estudar no Colégio de Aplicação da USP (Carrasco, 2007). O escritor tem boas memórias de sua vida no interior, filho de sua família de classe média, com ascendência espanhola, com precoce interesse por línguas estrangeiras. Ainda cursando jornalismo na ECA-USP, fez uma viagem de carona pela América, morou nos Estados Unidos e no México, ensinou português para sobreviver e fez traduções para uma editora mexicana.

Depois de formado, trabalhou para as principais revistas e jornais do país, antes de se tornar um conhecido escritor telenovelas. Carrasco começou a escrever para crianças durante a década de 1970, colaborando com a antiga revista Recreio. Ele publicou mais de trinta livros, traduções e adaptações de várias obras clássicas da literatura infantil, incluindo Dom Quixote, que foi publicado pela FTD em 2002 (reimpresso cinco vezes até 2012) e ilustrado por Alexandre Camanho. Carrasco foi o primeiro, depois de Lobato, a possuir copyrights, e consequentemente teve direito de transferir a edição de seus $\operatorname{livros}^{30}$. A recente reedição de sua tradução $e$ adaptação, como é designada, portanto assim assumida e lida em nossa pesquisa (Toury, 1995, p. 31-33) foi lançada pela editora Moderna em 2012 (quatro vezes reimpressa, também em formato digital), com texto revisado pelo próprio adaptador. O livro apresenta

\footnotetext{
${ }^{30}$ Suas obras incluem várias adaptações/ traduções para crianças de clássicos (tanto do cânon adulto como infantil), títulos imprescindíveis em qualquer biblioteca, reunidos em uma prestigiosa coleção, Biblioteca Walcyr Carrasco, editada pela Moderna, com a qual mantém um contrato de exclusividade.
} 
modificações substanciais do texto (nessa segunda edição dom Quixote não perde sua biblioteca, não há fogueira de livros, e todas as menções ao uso de bebidas alcoólicas é suprimido), com fontes e espaçamento maiores, menos ilustrações, e abundância de paratextos, entre eles, um ensaio de doze páginas, intitulado Dom Quixote, escrito pela professora da UNICAMP Marisa Lajolo. Tal como na primeira edição, há poucas notas de rodapé.

Walcyr Carrasco foi eleito para a Academia Paulista de Letras em 2008, segue escrevendo novelas que provocam alta audiência, crônicas para a revista Época, e promete mais livros para o público infantil e juvenil.

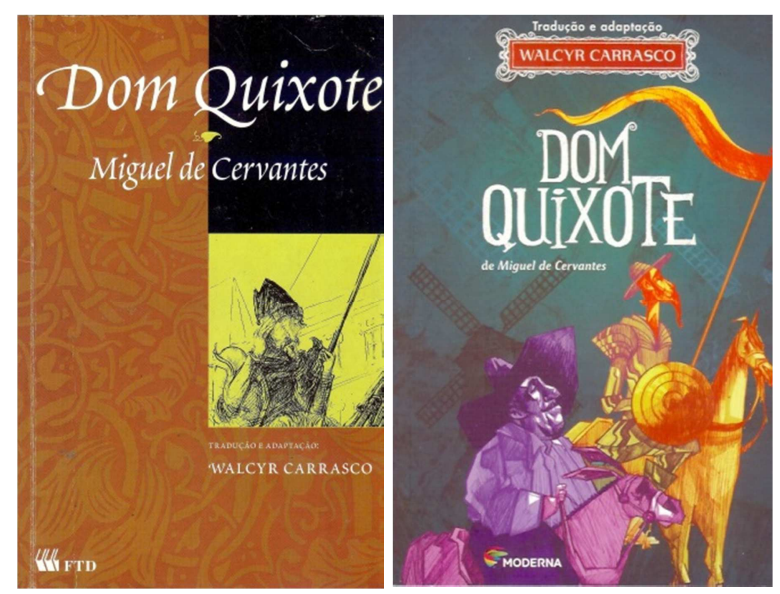

CEditora FTD, 2002@Editora Moderna, 2012

Leonardo Chianca, , de adaptador profissional a editor

Em 2005 surgiram várias reescrituras do Quixote. As obras de Chianca, Rios e Machado são as mais reeditadas (ou reimpressas, como dito, esses dados são frequentemente omitidos). Os próximos adaptadores responderam nossa entrevista.

Nascido em São Paulo em 1960, Leonardo Chianca combina as atividades de editor com aquelas de escritor de LIJ. Fundou a empresa Edições Jogo de Amarelinha, que produz e publica livros didáticos para editoras em todo o país. Depois de adaptar vários clássicos ${ }^{31}$, inclusive varias peças de Shakespeare, verteu Dom Quixote (2005), ilustrado pelo chileno Gonzalo Cárcamo (ambos detêm os direitos autorais) e republicado três vezes pela Difusão Cultural do Livro (DCL), uma empresa de pequeno

\footnotetext{
${ }^{31}$ Desde que lançou seu primeiro livro, já publicou trinta obras, quinze delas são adaptações. Afirmou ter optado por várias traduções em espanhol e português como fonte ao adaptar as cinco peças de Shakespeare, por não dominar a língua inglesa.
} 
e médio porte, fundada em 1967 e que edita principalmente livros infantis. A obra também está disponível em forma de audiolivro, com oito atores que interpretam as vozes dos mais de trinta personagens e do narrador da história.

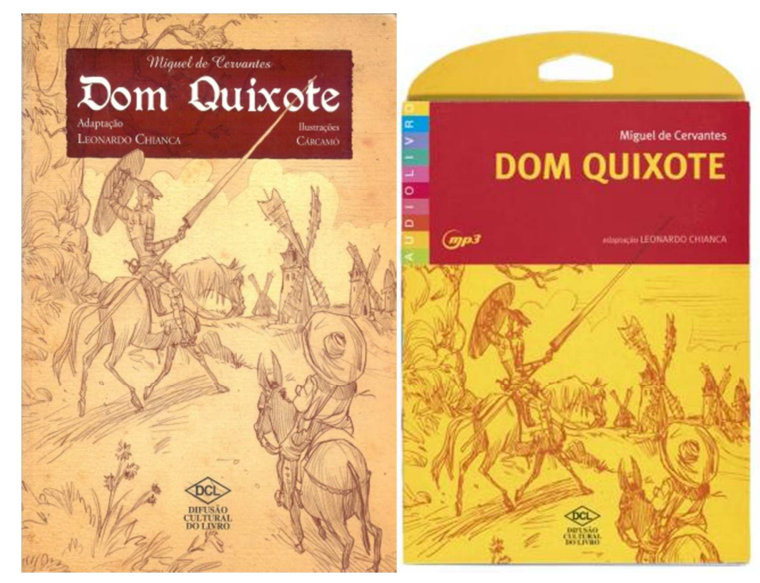

@Gonzalo Cárcamo, 2005 @Gonzalo Cárcamo, 2010 (audiolivro)

\section{Rosana Rios, escritora especializada em LIJ}

Rosana Rios nasceu em 1955, em São Paulo. Escreveu histórias em quadrinhos para a Disney ${ }^{32}$ e colaborou com a revista Recreio, mas, diferentemente de Carrasco e Machado, em 1988 seus primeiros livros não surgem de histórias para essa revista, mas de roteiros. Começou a escrever por acaso, contribuindo com o programa Bambalalão TV Cultura, mídia para qual adaptou os primeiros clássicos; também escreveu roteiros para TV Criança (1986) - TV Bandeirantes e Agente G (1995 a 1997) - TV Record.

Rios recebeu vários prêmios literários, tendo sido finalista do Prêmio Jabuti em 2008 e 2011. Junto com Eliana Martins escreveu a peça Um certo Dom Quixote (2009). Seu Dom Quixote foi publicado em 2005 pela Editora Escala Educacional, e em 2012 estava na sexta reedição e, tal como a versão anterior, pobremente ilustrado por Cárcamo $^{33}$. Fundada em 2004, é uma editora especializada em livros didáticos, desde a

\footnotetext{
${ }^{32}$ Em 2012 voltou a trabalhar com quadrinhos, desta vez adaptando as óperas Aida, A flauta mágica e $O$ guarani, para a coleção Ópera em quadrinhos da editora Scipione.

${ }^{33}$ Chianca assume a responsabilidade pelas ilustrações, que realmente deixam muito a desejar, inclusive confundem o leitor, com desenhos pouco atrativos. Cárcamo repetiu a mesma técnica nos dois Quixotes, produzindo figuras muito semelhantes àquelas feitas para a edição da adaptação assinada por Chianca, que também não parece satisfeito com o resultado final: "Indiquei o Cárcamo para a DCL, que aceitou e o contratou. O processo estava em andamento quando tive de correr com a produção do livro da Rosana, pela Escala Educacional. Aí tive a 'brilhante' ideia de chamar o Cárcamo, já que ele estava com a pesquisa em andamento, poderia ser mais rápido etc. Péssimas escolhas, nos dois casos. O Cárcamo é um profissional com muitos problemas. Posso contar ao vivo, se quiser saber detalhes, mas a DCL se desentendeu com ele e eu também. Penso que o resultado do trabalho é insatisfatório. Quanto à imagem da capa, foi uma solicitação minha de que fosse a cena dos moinhos de vento" (Chianca, apud Cobelo, 2015, p. 336).
} 
pré-escola até o ensino médio, A série Recontar Juvenil (antiga Reviver) é composta de 31 livros, a maioria com 88-96 páginas, e inclui títulos clássicos como Dom Quixote, com produção editorial encomendada a uma empresa terceirizada, Jogo da Amarelinha. Esse fato produziu uma situação curiosa, um adaptador do Quixote (Chianca) editando outra versão da obra cervantina.

Em seu longo catálogo de 140 títulos publicados, notamos poucas adaptações, apenas $7 \%$ do total. A primeira dessas dez reescrituras é o próprio Quixote, portanto Rosana Rios começou a adaptar clássicos para LIJ depois dessa experiência com a Escala Educacional. Essa editora também publica nove obras assinadas somente por ela, o que poderia explicar o motivo de ter aberto mão de seus copyrights como adaptadora.

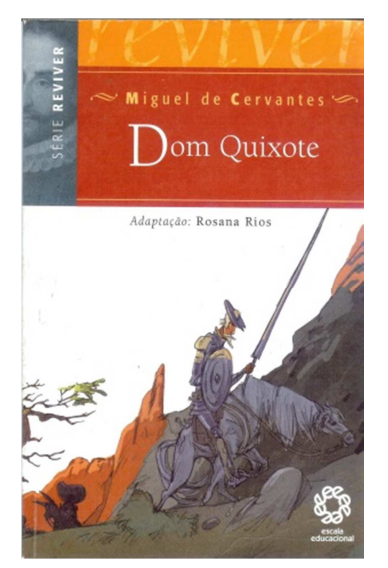

@Escala Educacional, 2005

\section{Ana Maria Machado, a premiada dama da LIJ}

Ana Maria Machado nasceu no Rio de Janeiro em 1941 e tem sido comparada a Lobato por sua grande produção de livros de excepcional qualidade literária para crianças e jovens. Recebeu vários prêmios importantes, incluindo o Hans Christian Andersen, a maior premiação no gênero, além de ser considerada, desde 1993, autora hors concours nos prêmios da Fundação Nacional do Livro para Crianças e Jovens (Fundação Nacional do Livro Infantil e Juvenil - FNLIJ). Machado tem mais de uma centena de livros publicados no Brasil e em mais de vinte outros países. Ela era uma professora de literatura da universidade até 1969, quando foi forçada ao exílio após ser presa pelo regime militar ${ }^{34}$. Mas antes disso, começou a escrever para a revista Recreio,

\footnotetext{
${ }^{34}$ Para melhor compreender os fatos narrados acima e seu exílio, falta adicionar um detalhe vital de sua biografia: sua família. Machado não somente é filha do senador Mário de Sousa Martins, cassado em 1969 pelo AI-5, mas também irmã do ex-ministro Franklin Martins, um dos responsáveis pelo sequestro
} 
a convite de sua ex-cunhada, Ruth Rocha, histórias que publicaria em foram de livros ao voltar. Na Europa, trabalhou como jornalista para a Elle Magazine e BBC; além de dar aulas de português na Sorbonne, escreveu uma tese sobre as obras de Guimarães Rosa, sob a supervisão de Roland Barthes.

A relação de Ana Maria Machado com o Quixote remonta à sua infância, quando conheceu as aventuras do cavaleiro contada por seu pai (Machado, 2004, p. 5). Em 1996, ela transformou o duo cômico em personagens de um de seus livros, Amigos Secretos. Ex-presidente da Academia Brasileira de Letras e grande defensora de adaptações, lançou sua adaptação em 2005, através da editora Mercuryo Jovem, com um longo e romântico ${ }^{35}$ título: $O$ cavaleiro do Sonho: As Aventuras de Dom Quixote de la Mancha, complementada pelas ilustrações de Portinari. O pequeno livro (54 páginas) recebeu prêmio hors concours de melhor adaptação da FNLIJ em 2006, e está atualmente em sua $13^{\text {a }}$ reimpressão (2013). Machado detém os direitos do texto, e, obviamente, a família de Portinari detém os direitos de suas obras. ${ }^{36}$

(4 de setembro de 1969) do embaixador americano Charles Burke Elbrick. Um dos carros usados na ação estava no nome de sua irmã Ana Maria. O documento e o manifesto estão disponibilizados integralmente, assim como as exigências feitas pelos militantes da Ação Libertadora Nacional (ALN), e do Movimento Revolucionário 8 de Outubro (MR-8), do qual Martins era membro. Site Franklin Martins. Disponível em: http://www.franklinmartins.com.br/estacao_historia_artigo.php?titulo=manifesto-do-sequestro-doembaixador-americano-rio-1969. Acesso em: 29 out. 2014.

${ }^{35}$ A escola romântica "adotou" o Quixote como obra representativa da escola. Até o século XVIII, a obra foi lida como um livro cômico, mas o romantismo alemão convenceu o mundo que o Quixote ressuscitava o espírito da cavalaria, retratando magistralmente os valores e costumes da Espanha de Felipe II, estabelecendo um caráter histórico-nacionalista na fortuna crítica da obra. Esse caráter patriota entusiasmou os primeiros românticos espanhóis, e o livro de Cervantes se transformou no paradigma do tradicionalismo da cultura espanhola, leitura que também agrada aos hispanistas de gerações posteriores até as primeiras décadas do século XX. Segunda essa leitura, o cavaleiro procurava realizar seu sonho, que seria defender os pobres e indefesos, promover a justiça, etc., sendo sempre mal interpretado. Ver mais em Anthony Close (2010/1978).

${ }^{36}$ As ilustrações foram originalmente feitos para ilustrar a primeira tradução brasileira do Quixote, escrito por Almir de Andrade (primeiro livro) e Milton Amado (segundo livro e todos os poemas), editado pela José Olympio em 1952; ver Cobelo (2010) para mais detalhes. Infelizmente, o artista morreu antes de completar o trabalho, deixando apenas 21 desenhos feitos com lápis de cor, e a edição foi publicada com ilustrações de Doré. Em 1973, esses desenhos foram publicados pela Diagraphis com 21 glosas assinadas por Carlos Drummond de Andrade. 


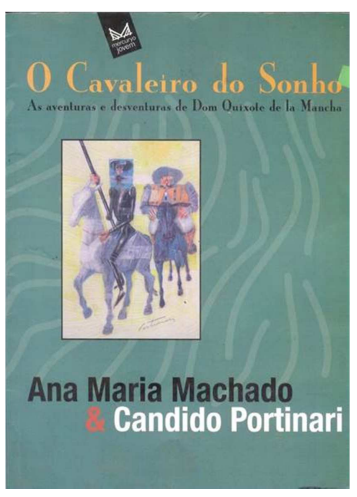

(C)João Candido Portinari, 2005

Fábio Bortolazzo Pinto, um adaptador eventual

Nascido em Santa Maria (RS) em 1974, este mestre em Letras (UFRGS) e docente do ensino médio e superior, distintamente dos nomes anteriores é um adaptador com uma biografia desconhecida e escassa produção literária, e não apenas por ser de longe o mais jovem do corpus a adaptar a obra, mas por realmente só ter seu nome em apenas outra obra além de sua adaptação do Quixote, uma tradução intralinguística do livro de Aluísio de Azevedo, O Cortiço (1998), informação omitida no site da editora, denotando uma perversa estratégia editorial ${ }^{37}$.

Assim como os responsáveis por quase todas as nossas traduções integrais do Quixote e alguns dos adaptadores vistos aqui, Pinto nunca apreendeu formalmente idiomas estrangeiros. Seu conhecimento de espanhol foi através da própria literatura e da proximidade geográfica com nossos vizinhos ${ }^{38}$.

O livro foi publicado todos os anos desde 2008, com ilustrações de Gilmar Fraga, um premiado quadrinista e diretor de arte do jornal Zero Hora de Porto Alegre. Na capa, como nas primeiras páginas do livro e créditos, há uma subtítulo: Dom

\footnotetext{
37 Apesar de assinar a apresentação, o posfácio e notas em sete obras publicadas pela LP\&M, em nenhuma delas lemos o nome de Bortolazzo Pinto no site: Eça de Queiroz: A correspondência de Fradique Mendes (1997); A cidade e as serras (1998); O primo Basílio (1998); O mandarim (1999); A ilustre casa de Ramires (1999), e Joaquim Manuel de Macedo: A moreninha (1997), A carteira de meu tio (2001).

38 "Quanto ao espanhol, [eu busquei o contato com o idioma espanhol por conta própria, principalmente textos e livros de autores argentinos e uruguaios], aprendi um pouco quando cursava a faculdade em Santa Maria. Só conheci, porém, realmente, as dinâmicas da língua (tanto escrita quanto falada) lendo Cortázar, Borges, Arlt, Garcia Márquez, Quiroga e Benedetti. [...] além de ter tido uma namorada uruguaia, o que ajudou bastante. [...] meu conhecimento da língua inglesa é bastante rudimentar".
} 
Quixote - Versão adaptada para neoleitores ${ }^{39}$, sugerindo um público leitor mais amplo do que as adaptações anteriores.

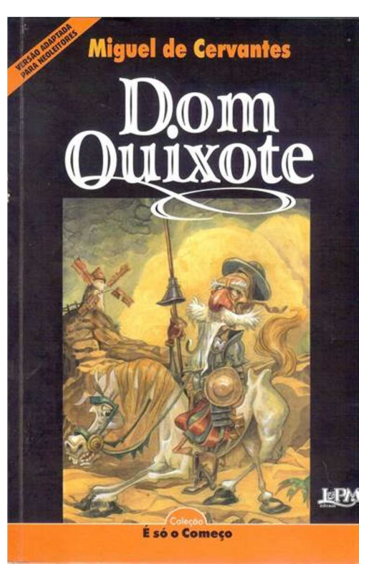

(CNewtec Editores, 2008

\section{Respostas sobre a autoridade do adaptador - trechos retirados das entrevistas feitas}

Os adaptadores entrevistados responderam a roteiros personalizados, sempre segundo as pesquisas feitas para cada indivíduo, mas propositalmente, alguns temas foram repetidos. Um deles foi sobre a autoridade percebida do tradutor/adaptador. Pergunta: Esta pesquisa procura compreender a autoridade do adaptador/tradutor como segundo autor. Qual foi seu grau de liberdade neste trabalho? Perguntamos

\footnotetext{
${ }^{39}$ Termo surgido em 2003 para designar adultos recém-alfabetizados. No exemplar do Quixote publicado pela L\&PM lemos: "Os livros da coleção $E$ só o Começo foram pensados e criados para homens e mulheres, jovens ou não, que estão começando a vida de leitor. Foram escolhidas histórias importantes e a linguagem foi adaptada para facilitar a leitura. Nosso maior desejo é que você leia e goste de ler" (Pinto, contracapa, 2010). O professor Daniel Weller afirma, em vídeo disponibilizado no site da editora, que "talvez para o pessoal da escola particular [o conteúdo da adaptação] seja pouco", e descreve o leitor típico da coleção: "85\% não ganharam na vida um livro de presente, vêm de residências com menos de 25 livros e se assustam com livros de duzentas páginas" L\&PM. Disponível em: https://www.youtube.com/watch?v=aBb989x5kDc. Acesso em 16 maio 2015. Anunciam em nota editorial que "O texto original foi reduzido em tamanho e a linguagem foi adaptada para um público específico, o de neoleitores, segundo critérios linguísticos (redução do repertório vocabular, supressão e mudança de pronomes, desdobramento de orações, preenchimento de sujeitos etc.) e literários (abertura de capítulos, desdobramento de parágrafos, reordenação de informações no tempo e no espaço, ênfase na caracterização de personagens etc.) que visam a oferecer uma narrativa fluente, acessível e de qualidade" (Pinto, 2014, p. 2). Por outro lado, Bortolazzo Pinto afirmou em nossa entrevista: "Nunca ouvi falar de um neoleitor que tenha lido minha adaptação do Quixote ou do Cortiço. Por outro lado, volta e meia fico sabendo de professores de séries finais do Ensino Fundamental que adotam, especialmente, a do Quixote”. (Pinto apud Cobelo, 2015).
} 
também se tinham tido alguma ingerência nas ilustrações, paratextos e notas de rodapés. Obtivemos as seguintes respostas ${ }^{40}$ :

LEONARDO CHIANCA: No meu caso, acredito ser um adaptador com autoridade sobre o texto resultante. Acredito que todo tradutor e/ou adaptador seja também autor, no sentido de que reescreve o texto, para o bem ou para o mal, conforme sua competência, suas escolhas e a edição que o livro recebe.

Quanto a sermos (considero-me um adaptador e não necessariamente um tradutor) um "segundo autor", como você sugere ou suspeita, pode ser ou não. Em certo ponto, creio que sou um segundo autor, mas me sinto arrogante ao dizer isso, pois não posso (nem quero) me comparar aos autores originais das obras que adapto. Sinto que sou coautor do texto resultante, mas não sou criador. $\mathrm{O}$ autor original é o criador e autor do texto original; o tradutor ou adaptador é apenas o autor do novo texto gerado, alguém que poderá permitir que aquela obra venha a ser conhecida de alguma forma.

Para a adaptação de Dom Quixote, na DCL, tive total liberdade para realizá-la. Eu coloquei a minha perspectiva sobre o tipo de adaptação que faria e a editora aceitou. Como eu fui convidado devido à minha experiência anterior (sete adaptações na Scipione), levei meu know-how para lá. Não houve nenhuma orientação específica em relação à linguagem, ao tamanho do texto, às escolhas que viria a fazer... nada. Eu mesmo decidi tudo. Não tive edição do meu texto, apenas uma preparação/revisão da Carla Mello, boa profissional que eu já conhecia como editor. A editora me enviou o texto diagramado e lido pela Carla.

Você me pergunta também sobre a questão dos direitos autorais. Trabalhar com textos em domínio público abre essa margem para a editora que publica, permitindo o pagamento de D.A. [direitos autorais]. Na DCL, recebo $10 \%$ de D.A. sobre todas as vendas. Na ocasião da escritura, pagaram-me um valor de adiantamento na entrega dos originais, estratégia usada como estímulo; depois esse valor é descontado nas prestações de contas futuras.

Nas adaptações que fiz para a Scipione, o D.A. é bem mais baixo, de $2 \%$, mas, em vez de adiantamento, havia um fee, um bom pagamento feito na entrega e que não era descontado depois. As minhas adaptações na Scipione vendem muito bem, algumas em torno de quase mil exemplares por mês.

\footnotetext{
${ }^{40}$ Infelizmente Gullar (ABL) e Carrasco (APL) voltaram recentemente a se manifestar positivamente e concordaram em responder nossa entrevista, mas não a tempo de incluir suas respostas neste artigo.
} 
Na Escala Educacional, o D.A. de 2\% foi copiado da Scipione, mas foram mais mesquinhos, e em lugar de fee havia adiantamento mesmo. Aliás, como editor dessa coleção na Escala Educacional, o Dom Quixote da Rosana Rios estava no grupo dos sete primeiros que encomendamos. E como a Rosana é uma nerd de carteirinha, foi a única a cumprir o prazo de entrega. Assim, foi o primeiro a ir para produção. [...] Aliás, mais uma curiosidade: a escolha dos sete primeiros livros da coleção da Escala Educacional foi feita baseado na lista dos mais vendidos da Série Reencontro, da Scipione, que é a campeã do mercado (o cara que criou a Escala Educacional era ex-diretor da Scipione/Ática e tinha essa lista na cabeça). O Dom Quixote era um dos três que mais vendiam na Scipione; o "meu” Romeu e Julieta era um deles... E segue sendo. ${ }^{41}$

ROSANA RIOS (não possui copyrights): Eu também escrevi esses paratextos a pedido da editora. Porém, eu acho que a biografia do Cervantes não foi escrita por mim... Ou eu fiz e eles ampliaram [o texto], não me recordo. Mas o "Dom Quixote fala sobre o quê" eu escrevi, com certeza, assim como as notas. [...] Eu só enviei e pronto. O projeto do livro era do Jogo de Amarelinha. Eles que resolveram tudo. Eu não dei palpite. [...]

MACHADO (conserva copyrights): Se meu grau de liberdade não fosse total, eu não faria. Ele foi limitado apenas por minha inteligência, minha sensibilidade e, hélas!, pelo número de páginas. [...] Os paratextos, como sempre, são da editora.

BORTOLAZZO PINTO (não possui copyrights): Puxei notas de rodapé quando achei necessário. [...] De qualquer forma, minha participação na adaptação foi esta: adaptar, colocar as notas, fazer o glossário e ceder os direitos. O resto foi feito pelo Garcez e pelo Fischer, sem me consultarem ou pedirem permissão. Tudo bem, o resultado não me desagrada, em absoluto.

\section{Algumas considerações}

Linda Hutcheon (2006, p. 143) chama a atenção para o que denomina "celebrity status", atribuindo um importante papel ao status de celebridade que pode ou não

\footnotetext{
${ }^{41}$ Uma observação: ao encomendar a adaptação para a Rosana, expliquei a ela o tipo de adaptação que queríamos, no sentido de manter contextos etc. Não me lembro ao certo, mas creio que a Rosana me escreveu perguntando algo sobre o enredo, mas não me lembro o quê. Pedi a ela que me enviasse um capítulo ou dois antes de prosseguir, e creio que não tive nada importante para pedir que fosse modificado. Tive a preocupação de não deixar transparecer nenhuma opinião ou dica de caminho, para que pudesse mesmo ser diferente do meu texto, que já estava pronto. Houve uma solicitação de tamanho feita à Rosana; creio que a encomenda foi de que o texto final deveria ter entre 80 mil e 100 mil caracteres com espaços, algo por aí.
} 
acompanhar uma reescritura. A importância, ou a grife ${ }^{42}$, dos envolvidos nas adaptações, define a colocação de uma adaptação dentro do mercado como a tradução de ..., que também ocorre no caso do Quixote. Como podemos apreciar pelas trajetórias dos adaptadores ${ }^{43}$, todos, com exceção de Fábio Bortolazzo Pinto e, em menor grau, José Angeli, possuem um respeitável currículo como escritores, e quase todos muito respeitados dentro da LIJ, incluindo os dois maiores nomes da literatura desse gênero, Monteiro Lobato e Ana Maria Machado, além de Walcyr Carrasco, conhecido roteirista da Rede Globo, e Ferreira Gullar, o grande poeta vivo brasileiro. Vários fazem ou fizeram parte de academias de Letras. O mesmo pode ser dito dos autores dos paratextos, intelectuais e/ou pesquisadores acadêmicos, com estudos relevantes sobre literatura para jovens ou escritores do gênero. É significativo, embora compreensível, que muitas das informações coletadas durante nossa pesquisa não sejam mencionadas nos paratextos,. Existem já experimentos que mostram a influência de um paratexto positivo ou negativo (Claassen, 2012) ${ }^{44}$, portanto não esperávamos encontrar uma biografia detalhada de Angeli contando seu passado como guerrilheiro ou como roteirista de quadrinhos eróticos; ou mencionando que uma idolatrada escritora infantil foi obrigada a escapar do Brasil ou que teve seu carro usado num sequestro, tampouco que o jovem gaúcho nunca escreveu outra obra depois da adaptação do Quixote. Procuramos responder aqui quem são os adaptadores da obra de Cervantes, como chegaram a essa hercúlea tarefa, suas fontes (declaradas ou subentendidas). As respostas das entrevistas (mesmo as não respondidas) nos obrigaram a uma profunda imersão

\footnotetext{
42 Mário Feijó Borges Monteiro (2006), que trabalha muito com a ideia de grife literária em sua dissertação, discorda de Leila Perrone-Moyses (1998), que segundo ele usa "o conceito de valor de grife de maneira a criticar certas técnicas de propaganda e marketing aplicadas pela indústria cultural ao tratar arte e literatura como mercadorias" (Monteiro, 2006, p. 99, marcas do autor). Esse pesquisador, assim como nós, utiliza o termo com o significado desenvolvido por Marisa Lajolo e Regina Zilberman (1988), que estudaram o relacionamento ente escritores e editores e escreveram sobre grifes literárias, exemplificando com o escritor que sonha em "ganhar muito dinheiro e converter-se em grife altamente rentável" (Lajolo e Zilberman, 1988: 63, marcas das autoras).

${ }^{43}$ Deixaremos o estudo dos editores e ilustradores para outro momento, mas adiantamos que vários são premiados e com carreiras bem-sucedidas dentro do mundo editorial.

${ }^{44}$ Eefje Claassen (2012, p. 22) seleciona dois grupos e apresenta o mesmo texto ficcional (de um escritor francês fictício, mas inspirado em uma pessoa real, Michel Houellebecq de conteúdo indigesto, moralmente repreensível, mas uma parte (A) recebe uma apresentação positiva do autor, e outra (B), uma negativa. Portanto o grupo A acredita que o escritor francês recebeu vários prêmios literários e que foi embaixador da UNICEF, aprova direitos iguais para homens e mulheres e luta contra todo tipo de discriminação racial. O segundo grupo leu uma apresentação na qual dizem que ele escreveu vários romances bem controversos, foi condenado por molestar crianças, além de racista e sexista. Os resultados são surpreendentes, e mostram que o interesse por um escritor ou a motivação para ler um determinado livro pode surgir pela impressão positiva ou negativa que temos desse escritor, imagem que influencia nossa forma de interpretar e valorar um texto literário (Claassen, 2012, p. 22).
} 
dentro de essas histórias de vida, possibilitando uma perspectiva diferente, a do autor, suas leituras preferidas, o primeiro contato com a obra cervantina, a história de como a adaptação foi parar naquelas mãos, informações que nos ajudam a entender a autoridade desses agentes nas obras estudadas ${ }^{45}$.

Os Quixotes do corpus acompanharam a evolução da sociedade brasileira, nosso sistema educacional e o crescimento demográfico. Por ser um dos primeiros clássicos adaptados e um livro tão famoso, esperávamos encontrar várias versões do Quixote ao longo do tempo. Uma das primeiras razões para justificar uma retradução e produzir uma nova versão de um livro já traduzido costuma ser a necessidade de atualizar o texto devido às constantes mudanças na cultura receptora, mas não foi bem isso que os dados recolhidos mostraram. Os adaptadores do nosso corpus, cujos textos seguem sendo publicados sem nenhuma alteração desde sua primeira edição, sinalizam uma boa aceitação de suas adaptações e leituras da obra de Cervantes. Mas existe também uma forte razão econômica. Obras como o Quixote fazem parte daquilo que se conhece como pots and pans ${ }^{46}$, isto é, o clássico que toda boa editora gostaria de ter em seu catálogo. Nenhuma editora pode lançar uma coleção ou série de clássicos sem incluir o livro de Cervantes.

\section{Referências}

ANGELI, José. A cidade de Alfredo Souza. Florianópolis: Letras Brasileiras, 2007. ARROYO, Leonardo. Literatura infantil brasileira. São Paulo: Melhoramentos, 1968. CAVALHEIRO, Edgard. Monteiro Lobato: Vida e obra. 2 vol. São Paulo: Brasiliense, 1962.

CLOSE, Anthony. The Romantic Approach to Don Quixote: A Critical History of the

\footnotetext{
${ }^{45}$ Segundo a definição de Milton e Bandia (2008, p. 1-2): os agentes são os indivíduos trabalhando nos bastidores editorais, como editores, revisores, promotores de venda e claro, tradutores; como também instituições e programas governamentais. Agência, ou patronagem, é um tema muito explorado por André Lefevere em mais de um ensaio (1985, 1992, 2005), e assunto recorrente em estudos literários. Além de justificar-se nestas discussões sobre retradução, pode ser utilizado para discutir reescrituras em geral. Nesse sentido, John Milton (2002, 2009), Kaisa Koskinen e Outi Paloski (2003), e também Emer O“ Sullivan (2009) são pesquisadores que se inquietam com essa importante variável congregada com o nome de agência, elemento cada vez mais presente em toda ponderação que envolva um produto editorial. E essa conjuntura, apesar de mais acirrada agora, nesta era digital, é tão antiga quanto a literatura, música, teatro e qualquer atividade artística que resulte em um produto, tangencial ou não.

${ }^{46} \mathrm{O}$ conceito de pots and pans foi retirado do livro de Tahir Gürçağlar (2008: 297): "These classics were indispensable for publishers as pots and pans are in a kitchen" [Estes clássicos eram indispensáveis para editoras como são as panelas e frigideiras em uma cozinha].
} 
Romantic Tradition in Quixote Criticism. Cambridge: Cambridge University Press, 2010/1978.

CLAASSEN, Eefje. Author Representations in Literary Reading. Amsterdam e Philadelphia: John Benjamins, 2012.

COBELO, Silvia. Historiografia das traduções do Quixote publicadas no Brasil:

Provérbios do Sancho Pança. São Paulo, 2009. 235p. Dissertação (Mestrado em Letras) - FFLCH, Universidade de São Paulo.

. "Os tradutores do Quixote publicados no Brasil". Tradução em Revista 8, 1-36, 2010. Disponível em: http://www.maxwell.vrac.pucrio.br/trad_em_revista.php?strSecao=input0. Acesso em 13 maio 2015.

. Breaking boundaries - Don Quijote made in Brazil. In: 4th Conference of the

International Association for Translation and Intercultural Studies (IATIS), 2012, Belfast: Book of Abstracts IATIS Conference 2012, 2012. v. 1. p. 107-108.

As adaptações do Quixote no Brasil (1886-2013): Uma discussão sobre retraduções de clássicos da literatura infantil e juvenil. São Paulo, 2015. Tese (Doutorado em Letras) - FFLCH, Universidade de São Paulo.

DE ALENCAR ACIOLI, Socorro E. De Emília a Dona Quixotinha. Fortaleza, 2004. Dissertação (Mestrado em Letras) - Centro de Humanidades, Univ. Federal do Ceará.

EXÉRCITO BRASILEIRO. Orvil: A resposta do exército brasileiro. Apresentação: USTRA, Coronel Carlos Alberto Brilhante. Brasil: Exército Brasileiro, 1988. Disponível em: http://www.averdadesufocada.com/images/orvil/orvil_completo.pdf. Acesso em: 10 dez. 2014.

FLYNN, Peter. Genre and Context In Translation Research. Aula CETRA. Leuven: University of Leuven, 2013.

GUEDES, Sandra. Orígenes Lessa e a Propaganda Brasileira. Dissertação (Mestrado em Comunicação Social) - Universidade Metodista de São Paulo, 2007.

GÜRÇAĞLAR, Şehnaz Tahir. The Politics and Poetics of Translation in Turkey, 1923-1960. Amsterdam/New York: Rodopi, 2008.

HALLEWELL, Laurence. O livro no Brasil. Trad. Maria da Penha Villalobos, Lólio Lourenço de Oliveira e Geraldo Gérson de Souza). São Paulo: EDUSP, 2005.

HOHLFELDT, Antônio. Deus escreve direito por linhas tortas: o romance-folhetim 
dos jornais de Porto Alegre entre 1850 e 1900. Porto Alegre: EDIPUCRS, 2003. HUTCHEON, Linda. A Theory of Adaptation. London/New York: Routledge, 2006.

KOSKINEN, Kaisa; PALOPSKI, Outi. Retranslations in the Age of Digital Reproduction. Cadernos de Tradução 11 (1):19-38, 2003.

LAYTANO, Dante. Palavras para a presente edição. In: JANSEN, Carlos. O patuá.

Porto Alegre: Instituto de Filosofia e Ciências Humanas da UFRGS, 1974.

LEFEVERE, André. Translation, Rewriting and the Manipulation of Literary

Fame. London/New York: Routledge, 1992.

Why Waste our Time on Rewrites? The Trouble with Interpretation and the

Role of Rewriting in an Alternative Paradigm. In: HERMANS, Theo (Ed.) The

Manipulation of Literature: Studies in Literary Translation. London/Sidney:

Croom Helm, 1985. p. 215-243.

. Mother Courage's Cucumbers: Text, System and Refraction in a Theory of

Literature. In: Venuti, Lawrence (Ed.) The Translation Studies Reader.

London/New York: Routledge, 2004/1982. p. 239-255

LOBATO, Monteiro. A Barca de Gleyre (Vols. 1 e 2). São Paulo: Editora Brasiliense, 1957.

. Conferências, artigos e crônicas. São Paulo: Editora Brasiliense, 1959.

. Cartas escolhidas (Vols. 1 e 2). São Paulo: Editora Brasiliense, 1957.

MACHADO, Ana Maria. Como e por que ler os clássicos universais desde cedo. Rio de Janeiro: Objetiva, 2002.

Apresentação. In: HARRISSON, Michael. Dom Quixote. Ilustrações por Victor Ambrus. Trad. Luciano Vieira Machado. São Paulo: Ática, 2004.

MARTINS, Marcia do Amaral Peixoto. A Instrumentalidade do Modelo Descritivo para a Análise de Traduções: O caso dos Hamlets brasileiros. São Paulo, 1999. Tese (Doutorado em Comunicação e Semiótica) - Programa de Estudos PósGraduados em Comunicação e Semiótica, Pontifícia Universidade Católica de São Paulo. Disponível em: http://www.dbd.pucrio.br/shakespeare/pdfs/hamlets_brasileiros.pdf. Acesso em: 13 maio 2015.

MILTON, John. The Figure of the Factory Translator. In: HANSEN, Gyde; MALMKJAER, Kirsten; GILE, Daniel (Eds.) Claims, Changes and Challenges in Translation Studies. Amsterdam/Philadelphia: John Benjamins, 2001a. p. 169180. 
. The Translation of Classic Fiction for Mass Markets. The Case of a Brazilian Book Club, the Clube do Livro. In: The Translator 7:1, p. 43-69, $2001 \mathrm{~b}$.

O Clube do Livro e a Tradução. Bauru: EDUSC, 2002.

. Monteiro Lobato and translation: 'Um país se faz com homens e livros'. DELTA: Documentação de Estudos em Lingüística Teórica e Aplicada, Special issue 19), p. 117-132, 2003. Disponível em: www.scielo.br/scielo.php?script=sci_arttext\&pid=S0102$44502003000300008 \& \operatorname{lng}=$ en\&tlng=en. $\quad 10.1590 /$ S0102-44502003000300008. Acesso em 13 maio 2014.

MILTON, John; BANDIA, Paul (Eds.). Agents of Translation. Amsterdam: John Benjamins, 2008.

MIECOANSKI, Ellen Trilha de Livros. Gazeta do Povo (Curitiba, 13 dez. 2012). Disponível em: http://www.gazetadopovo.com.br/falecimentos/conteudo.phtml?id=1327545\&tit=T rilha-de-livros. Acesso em 14 maio 2015.

MONTEIRO, Mário Feijó Borges. Permanência e mutações: O desafio de escrever adaptações escolares baseadas em clássicos da literatura. Rio de Janeiro, 2006. Tese (Doutorado em Letras). Programa de Pós-Graduação em Letras, Pontifícia Universidade Católica do Rio de Janeiro.

O'SUlLIVAN, Emer. Comparative Children's Literature. London/New York: Routledge, 2005.

PINHEIRO SALLES, Antonio. Confesso que peguei em armas. Goiânia: Universidade Federal de Goiás, 2008.

PRADO, Amaya Obata Mouriño de Almeida. Adaptação, uma leitura possível: Um estudo de 'Dom Quixote das crianças', de Monteiro Lobato. Três Lagoas, 2007. Dissertação (Mestrado em Letras) - Faculdade de Letras, Univ. Federal do Mato Grosso do Sul.

PYM, Anthony. Method in Translation History. Manchester: St. Jerome, 1998. Humanizing Translation History. In: Hermes - Journal of Language and Communication Studies, n. 42, 2009. Disponível em: http://usuaris.tinet.cat/apym/online/research_methods/2008_Hermes.pdf?pagewanted=all. Acesso em 13 maio 2015. 
RILEY, Edward C. La singularidad de la fama de don Quijote. Cervantes: Bulletin of the Cervantes Society of America, 22:1, p. 27-41, 2002.

SANDERS, Julie. Adaptation and Appropriation. London: Routledge, 2013.

SILVA, Fabricio Trevisan Florentino da. História e guerrilha: Entre a tradição rural e a prática urbana. Franca, 2012. Dissertação (Mestrado em História) - Faculdade de Ciências Humanas e Sociais, Universidade Estadual Paulista Júlio de Mesquita Filho.

SORIANO, Marc. La literatura para niños y jóvenes: guía de exploración de sus grandes temas. Trad. Graciela Montes. Buenos Aires: Ediciones Colihue, 1995.

TOURY, Gideon. Descriptive Translations Studies and Beyond. Amsterdam: John Benjamins, 1995.

VENTURA, Maria Isabel Pinto (Ed.). Dos presos políticos brasileiros. Lisboa: Edições Maria da Fonte, 1976.

VENUTI, Lawrence. Translation Changes Everything: Theory and Practice. London/ New York: Routledge, 2013.

WILliAMS, Jenny; CHESTERMAN, Andrew. The Map - A beginner's guide to doing research in Translation Studies. Manchester, UK \& Northampton, MA: St. Jerome Publishing, 2002.

ZILBERMAN, Regina; LAJOLO, Marisa. Um Brasil para crianças. Para conhecer a literatura infantil brasileira: história, autores e textos. São Paulo: Global, 1986.

\section{Obras Analisadas}

ANGELI, José. Dom Quixote, o cavaleiro da triste figura. São Paulo: Scipione, 1985, 2002, 2013.

ANGELI, José. Dom Quixote. São Paulo: Scipione, 2003.

CARRASCO, Walcyr. Dom Quixote. São Paulo: FTD, 2002.

Dom Quixote. São Paulo: Moderna, 2012 [edição revisada].

CERVAnteS, Miguel de. Don Quijote de la Mancha. Francisco Rico (ed.). Barcelona: Editorial Crítica, 2001.

CERVANTES, Miguel de; PORTINARI, Cândido; ANDRADE, Carlos Drummond de.

D. Quixote. Diagraphis: São Paulo, 1973.

CHIANCA, Leonardo. Dom Quixote. São Paulo: Difusão Cultural do Livro, 2005, 
2012.

GULLAR, Ferreira. Dom Quixote de la Mancha. Rio de Janeiro: Revan, 2002.

JANSEN, Carlos. D. Quixote de la Mancha. Rio de Janeiro - São Paulo - Recife: Laemmert \& C, 1901.

JANSEN, Carlos; SENNA, Terra. Dom Quixote de la Mancha. Rio de Janeiro: Minerva e MCA, (1956, 195?, 1982).

LESSA, Orígenes. Dom Quixote. São Paulo: Ediouro, (1971, 2001, 2005).

LOBATO, Monteiro. Dom Quixote das Crianças. São Paulo: Cia Editora Nacional, 1936.

. Dom Quixote das Crianças. São Paulo: Brasiliense [várias coleções e formatos diferentes], 1944-2005.

Dom Quixote das Crianças. São Paulo: Editora Globo, 2010.

MACHADO, Ana Maria; PORTINARI, Candido. O Cavaleiro do Sonho: As aventuras e desventuras de Dom Quixote de la Mancha. São Paulo: Mercuryo Jovem, 2005.

PINTO, Fábio Bortolazzo. Dom Quixote. São Paulo: LP\&M, 2008, 2010.

QUILES, Margarita Barberá. Don Quijote de la Mancha. São Paulo : Scipione. [com CD], 2006.

RIOS, Rosana. Dom Quixote. São Paulo: Escala Educacional, 2005.

SIMAS, André. Dom Quixote das Crianças adaptado da obra de Monteiro Lobato. São Paulo: Editora Globo, 2007. 